\title{
Study of duodenal ulcer disease in 100 families using total serum pepsinogen as a genetic marker
}

\author{
C M HABIBULLAH, M MUJAHID ALI, M ISHAQ, R PRASAD, \\ B PRATAP, AND Y SALEEM
}

From the Departments of Gastroenterology and Biochemistry, Osmania General Hospital and Department of Genetics, Osmania University, Hyderabad, India

SUMMARY Although various markers have been used in attempts to elucidate the mode of inheritance of duodenal ulcer, they have not significantly contributed to a clear understanding of the problem. In the present study total serum pepsinogen was used as a genetic marker and its concentrations were estimated in 100 ulcer patients and their family members up to three generations. Eighty three per cent of the ulcer patients had hyperpepsinogenaemia on a familial basis, and it followed an autosomal dominant mode of inheritance. Thus a large majority of ulcer patients have associated hyperpepsinogenaemia which forms a genetic basis of their disease. The remaining $17 \%$ ulcer patients did not have associated hyperpepsinogenaemia nor was the ulcer inherited by the family. Based on these observations we wish to suggest that duodenal ulcer associated with hyperpepsinogenaemia may be considered a genetic disease. This type may be termed 'primary duodenal ulcer'. In the remaining patients without hyperpepsinogenaemia or affected relatives the ulcer may be called 'secondary duodenal ulcer'. Thus total serum pepsinogen may be considered a reliable genetic marker in helping to delineate the genetic disorder from the non-genetic, thereby improving the predictive ability in duodenal ulcer.

Several workers have suggested the role of genetic factors in the pathogenesis of duodenal ulcer disease. $^{12}$ The observations reported increased frequency of the disease in first degree relatives of patients, greater concordance between monozygotic twins than dizygotic twins, ${ }^{3}$ and the association of ABO blood groups with the disorder. ${ }^{45}$ Reports on the familial aggregation of this disease, however, did not reveal a definite mode of inheritance. This difficulty encountered in elucidating the mode of inheritance of duodenal ulcer is usually attributed to the absence of appropriate genetic markers for the ulcer diathesis. The genetic markers used in the past are $\mathrm{ABO}$ blood groups, ${ }^{45}$ secretor and non-secretor status, ${ }^{5}$ HLA typing ${ }^{6}$ and serum pepsinogen-I. ${ }^{12}$ Rotter et $a l^{1}$ using serum pepsinogen-I concentrations as a subclinical marker found that ulcer patients may be either hyperpepsinogenaemic-I or normopepsinogenaemic-I; the segregation analysis of hyperpepsinogenaemic-I duodenal ulcer in their study agreed with an autosomal dominant mode of inheritance. The frequency of duodenal ulcer in

Address for correspondence: Dr C M Habibullah, Department of Gastroenterology, Osmania Medical College, Hyderabad (AP), India.

Received for publication 10 February 1984 normopepsinogenaemic individuals could not be explained similarly, however, and was attributed to genetic heterogeneity of the disease.

Considering the magnitude of the problem of duodenal ulcer in India we undertook a similar study using total serum pepsinogen concentrations as the marker and have analysed the mode of segregation of serum pepsinogen in families of 100 patients.

\section{Methods}

SUBJECTS

During the period July 1980 to July 1982, 100 duodenal ulcer patients of either sex aged 16-70 years (mean age $39 \cdot 1 \pm 13 \cdot 3$ ) were studied at the Department of Gastroenterology, Osmania General Hospital, Hyderabad. Family data were recorded up to a maximum of three generations. The study also includes 505 family members comprising of 153 sibs, 55 parents, 273 children and 24 grandchildren. Because selection of patients was based on endoscopic findings there was no scope of any bias in the sample with respect to hyperchlorhydria or hyperpepsinogenaemia.

Total serum pepsinogen concentrations in 100 
age-matched healthy male and female subjects 16-70 years (mean age 38.1 $\pm 13 \cdot 3$ ) and 14 children below 14 years who did not have any family history of ulcer disease served as controls. Family members of the patients below the age of 14 years were also investigated to assess the age at which adult normal range of total serum pepsinogen concentrations are reached.

Blood samples were collected from patients and their family members for the estimation of total serum pepsinogen concentrations.

These were determined by the method of Mirsky et al, ${ }^{7}$ using haemoglobin as substrate.

In order to see the mode of inheritance of total serum pepsinogen concentrations in the duodenal ulcer families, segregation analysis was carried out by the method suggested by Morton, ${ }^{8}$ families having been ascertained by incomplete single selection.

Chi square test was used to see whether the observed segregation ratio approximated the predicted ratio of 0.5 assuming that all marriages were between an affected and a normal person.

\section{Results}

The mean values obtained for total serum pepsinogen concentration in healthy controls and in patients suffering from duodenal ulcer along with the mean total serum pepsinogen concentrations obtained in the family members of the patients are given in Table 1, from which it is apparent that the mean concentrations differed considerably between men and women. The range of values obtained in either sexes was 350-750 units in men and 300-650 units in women, so that any value beyond 750 units in men and 650 units in women was regarded as hyperpepsinogenaemia. In children below 14 years of age the total serum pepsinogen concentrations ranged from 250-450 units. Mean total serum pepsinogen concentration in male patients with duodenal ulcer was significantly raised when compared with the concentrations obtained for male controls $(p<0 \cdot 001)$, similarly the total serum pepsinogen concentration in female patients was significantly greater than their controls $(p<0.001)$. Only eight men and nine women among the patients had normopepsinogenaemia. No patient under 14 years of age with duodenal ulcer was encountered.

Among the family members 19 had clinical ulcer disease. For purpose of comparison they were divided as those with and without ulcer. Of those who had an ulcer 14 were men and five women; all were hyperpepsinogenaemic. No normopepsinogenaemic duodenal ulcer patient was detected in the families. Other family members who were not affected, had either hyperpepsinogenaemia or normopepsinogenaemia.

In the case of family members below 14 years of age the mean total serum pepsinogen concentration was $603.8 \pm 44.89$ units. This is high in comparison with their controls in whom it did not reach the adult normal range, as they may still be growing and their chief cell mass may not have reached the maximum. For these reasons children below 14 years were excluded from the genetic analysis.

When the total serum pepsinogen concentration of patients was analysed it was observed that $83 \%$ of the patients were hyperpepsinogenaemic while $17 \%$ of the patients were normopepsinogenaemic. Among the family members of hyperpepsinogenaemic patients of duodenal ulcer $57.28 \%$ were hyperpepsinogenaemic while $42.72 \%$ were normopepsinogenaemic. In case of normopepsinogenaemic patients all the family members had normopepsinogenaemia except in one family where the husband of the proposita was hyperpepsinogenaemic as a result of which hyperpepsinogenaemia was recorded in $2 / 4$ of the family members (Table 2).

Segregation analysis of high total serum pepsinogen concentrations in sibships of hyperpepsinogenaemic patients gave a segregation frequency of $0.56 \pm 0.026$. On comparison with the predicted ratio of 0.5 for a dominant and 0.25 for a recessive mode of inheritance, we arrive at an autosomal dominant mode of inheritance for hyperpepsinogenaemia.

Table 1 Mean total serum pepsinogen concentrations in controls, patients of duodenal ulcer and their family members

\begin{tabular}{lllll}
\hline S1 no. & Category & Controls & Patients & Family members \\
\hline 1 & Men & $521 \cdot 5 \pm 117 \cdot 46(70)$ & $961 \cdot 12 \pm 208 \cdot 62(83)^{*}$ & $757 \cdot 5 \pm 183 \cdot 73(215)^{*}$ \\
2 & Women & $427 \cdot 5 \pm 94 \cdot 65(30)$ & $821 \cdot 90 \pm 281 \cdot 4(17)^{*}$ & $629 \cdot 7 \pm 151 \cdot 97(158)^{*}$ \\
3 & Children below 14 years & $351 \cdot 4 \pm 80 \cdot 71(14)$ & - & $603 \cdot 8 \pm 138 \cdot 9(132)^{*}$ \\
\hline
\end{tabular}

Results are expressed as $\mathrm{U} / \mathrm{ml} / 24 \mathrm{~h}$. Mean $\pm \mathrm{SD}$.

Figures in parentheses represent number of observations.

$*(p<0.001)$. 
Table 2 Occurrence of normopepsinogenaemia and hyperpepsinogenaemia in patients of duodenal ulcer and their family members

\begin{tabular}{lccc}
\hline Category & No & Normopepsinogenaemia & Hyperpepsinogenaemia \\
\hline Patients & 100 & $17(17 \%)$ & $83(83 \%)$ \\
Family members of hyperpepsinogenaemic patients & 309 & $132(42 \cdot 72 \%)$ & $177(57 \cdot 28 \%)$ \\
Family members of normopepsinogenaemic patients & 64 & $62(96 \cdot 88 \% *)$ & $2\left(3 \cdot 12 \% \%^{*}\right)$ \\
\hline
\end{tabular}

* These values become $100 \%$ and zero when it is considered that hyperpepsinogenaemia was introduced into one family by the husband of the proposita.

\section{Discussion}

The familial basis of duodenal ulcer and its mode of inheritance have thus far been an enigma, resulting in the emergence of the polygenic hypothesis ${ }^{9}$ and the concept of genetic heterogeneity. ${ }^{10}$ Rotter $e t a l^{2}$ studied the mode of inheritance of hyperpepsinogenaemia-I and concluded that it was an autosomal dominant disorder. Their study, however, was restricted to two large kindreds. In the above mentioned study Rotter $e t \mathrm{al}^{2}$ reported that the ulcer patients tended to have either hyperpepsinogenaemia-I or normopepsinogenaemia-I on a familial basis and that hyperpepsinogenaemia-I accounted for $50 \%$ of the duodenal ulcers. As the other $50 \%$, a sizable number, could not be accounted for on the basis of hyperpepsinogenaemia-I, they thought that normopepsinogenaemia and ulcer disease had also aggregated on familial basis so that duodenal ulcer with hyperpepsinogenaemia-I and duodenal ulcer with normopepsinogenaemia-I were considered as two definite genetically determined entities. In the present communication we report the results of our study of 100 patients of duodenal ulcer and their family members up to three generations, not confining ourselves to the sibships of the patients. The genetic marker used in our study was total serum pepsinogen. It is interesting to note that genetic studies pertaining to duodenal ulcer disease have not so far been reported using this marker.

Rotter and colleagues studied the mode of inheritance of duodenal ulcer using serum PG-I as the marker with the understanding that as PG-I arises from the proximal stomach it might be a better marker of oxyntic mucosal structure and functions than serum PG-II or total pepsinogen levels. Our contention is, though the proximal stomach bears the major part of the chief cell mass the site of ulcer formation is predominantly in the upper part of the duodenum which bears the brunt of the injury and the disintegrating peptic cells of the area may be constantly releasing PG-II into the serum thereby causing an increase in concentrations of serum PG-II. Hence total serum pepsinogen may be a better serum marker of duodenal ulcer, and in fact Mirksy observed a tendency for higher values of total serum pepsinogen among patients with active lesions.

Plebani et $a l^{11}$ recently showed a positive correlation between total serum pepsinogen concentrations and serum pepsinogen-I levels in normal subjects as well as in patients with both gastric and duodenal ulcer, which implies that increase in serum pepsinogen-I is part of an overall increase in total serum pepsinogen levels. The present study revealed that on this basis familial aggregation of hyperpepsinogenaemia and ulcer disease occurred in $83 \%$ of the patients. The inheritance of hyperpepsinogenaemia according to our results could be doubtlessly considered to suggest an autosomal dominant mode with complete penetrance. As long as duodenal ulcer was studied using phenotypic characteristic like hyperpepsinogenaemia-I and normopepsinogenaemia-I, there was considerable overlap between the control and patient populations. A comparison of the frequency distribution curve of total serum pepsinogen concentrations in controls and duodenal ulcer patients showed minimum overlapping (Figure),

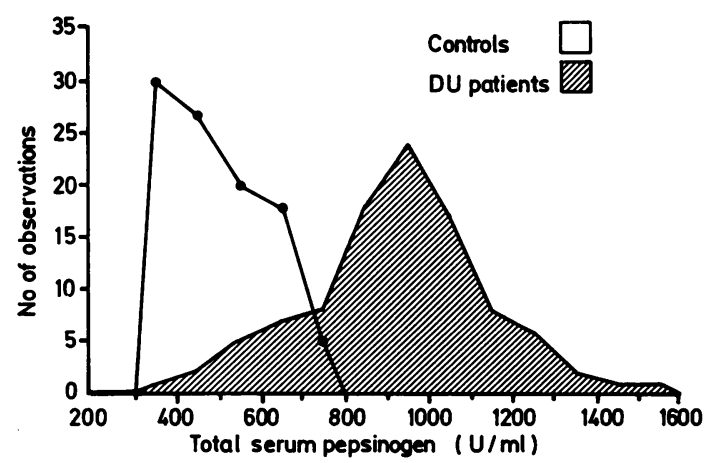

Figure Frequency distribution of total serum pepsinogen in duodenal ulcer patients and in control populations.

Overlap represents $17 \%$ of ulcer patients whose pepsinogen concentrations fell in the control range. 
while serum pepsinogen-I concentrations presented considerable, $(50 \%)$ overlap between the two populations as in the study of Rotter $e t$ al. ${ }^{2}$

This suggests that duodenal ulcer is primarily associated with high concentrations of total serum pepsinogen because irrespective of its site of origin and immunological characteristics it is the precursor of pepsin. Further the level of serum pepsinogen correlates positively with the level of pepsin in the gastric lumen and may definitely contribute to the pathogenesis of an ulcer while the genetically transmitted high levels of serum pepsinogen may indicate the presence of the ulcer diathesis. We wish to suggest that duodenal ulcer with concomitant hyperpepsinogenaemia be considered as 'primary duodenal ulcer' as the association observed between the two appears to be the rule. It is interesting to note that $54.2 \%$ of these patients belonged to blood group $\mathrm{O}$ another genetic marker of duodenal ulcer.

In a small percentage $(17 \%)$ of the ulcer patients, hyperpepsinogenaemia was not associated with the disease nor was there association with blood group $\mathrm{O}$ because only $23.52 \%$ of patients belonged to that group, while $54.2 \%$ of hyperpepsinogenaemic duodenal ulcer patients did belong to it. Furthermore there was no inheritance of duodenal ulcer seen in the families of these patients with normopepsinogenaemia and duodenal ulcer. Though the numbers are small this may indicate that these ulcers are the result of neuroendocrinological or environmental factors, which are also known to cause ulcer disease. Such a duodenal ulcer may then be considered as 'secondary duodenal ulcer'. In contrast with this 19 patients of duodenal ulcer were encountered among the (309) family members of 83 hyperpepsinogenaemic duodenal ulcer patients and hyperpepsinogenaemia was again associated with their ulcer pointing to its genetic aetiology. Moreover statistically the observed difference $(6 \cdot 15 \%)$ between the two samples was 4.9 times its standard error $(1.24)$ hence we conclude that the difference is real.

In the light of this classification duodenal ulcer patients manifesting hyperpepsinogenaemia require further investigation in the family to identify siblings and progeny carrying the trait and thus, at higher risk, so that they could be shielded from aggravating environmental and other factors. On the contrary a duodenal ulcer patient with normopepsinogenaemia may safely be considered to be suffering from non-genetic or 'secondary duodenal ulcer' which does not entail investigating the serum pepsinogen concentration in the family. Being secondary, however, it may enjoin a search for the primary cause and thus aid in exposing an occult disease.

\section{References}

1 Rotter JI, Sones JQ, Samloff IM, et al. Duodenal ulcer disease associated with elevated serum pepsinogen-I. An inherited autosomal dominant disorder. $N$ Engl $J$ Med 1979; 300: 63-5.

2 Rotter JI, Petersen G, Samloff IM, et al. Genetic heterogeneity of hyperpepsinogenemic I and normopepsinogenemic I duodenal ulcer disease. Ann Intern Med 1979; 91: 372-7.

3 Gotlieb-Jensen K. Peptic ulcer: genetic and epidemiological aspects based on twin studies. Copenhagen: Munksgaard, 1972.

4 Langman MJS. Blood groups and alimentary disorders. Clin Gastroenterol 1973; 2: 497-506.

5 McConnell RB. Gastric and duodenal ulcer. The genetics of the gastrointestinal disorders. London: Oxford University Press, 1966: 76-101.

6 Ellis A, Woodrow JC. HLA and duodenal ulcer. Gut 1979; 9: 760-2.

7 Mirsky IA, Futterman P, Kaptan S, BroH K'ahn RH. Blood plasma pepsinogen. J Lab Clin Med 1952; 40: 17-26.

8 Morton NE. Genetic tests under incomplete ascertainment. Am J Hum Genet 1959; 11 (1): 1-16.

9. Cowan WK. Genetics of duodenal and gastric ulcer. Clin Gastroenterol 1973; 2: 539-45.

10 Rotter JI, Rimoin DL. Peptic ulcer disease - A heterogeneous group of disorder? Gastroenterology 1977; 73: 604-7.

11 Plebani M, Di Masio F, Vianello F, et al. Pepsinogen group I radioimmunoassay and total serum pepsinogen colorimetric determinations: a comparative study in normal subjects and in peptic ulcer patients. Clin Biochem 1983; 16: 20-2. 